\title{
ASHES OF HISTORY: COLUM MCCANN'S ZOLI
}

\author{
Eluned Summers-Bremner
}

University of Auckland, NZ

\begin{abstract}
:
My essay reads Colum McCann's novel Zoli as an elaboration of the ethical work of poetry. In the novel the Slovakian poet Zoli Novotna, based on the life and work of the Polish Romani balladeer Papusza (Bronislawa Wajs), is irreversibly disowned by her people upon publishing poetry that is used, as is her image, to represent the enaction of Law 74, or the Big Halt, in the 1950s and 1960s. Disastrously, this process caused Eastern European Gypsies to lose their sense of belonging and livelihood through the confiscation of caravans, their being forced into apartment blocks in towns, and consequent opposition to traditional Gypsy skills, most of which were lost. McCann's novel extends Papusza's story beyond her exclusion from her people, having Zoli bear performative witness to the mistaken work her poetry once did. In walking roads from which Roma have been banished, and in taking on the bare remains of her lost identity, a mishmash of gadzi perceptions, Zoli makes the nothingness for which she stands into the means of travel and future hope for others. In my reading, the novel elaborates a claim that justice is not served by forcing everyone to have the same degree and kind of pleasures, but by allowing forms of chosen deprivation. The ashes of Zoli's burned poems become
\end{abstract}

\begin{tabular}{|l|l|l|l|l|}
\hline Ilha do Desterro & Florianópolis & $n^{\circ} 54$ & p. 061-081 & jan./jun. 2008 \\
\hline
\end{tabular}


the ashes of a reconstituted identity around a space that holds nothing, equivalent to the nothing that gadzos are willing to know about Romani world-making and belonging, and with which Zoli has become unwittingly, yet not, as the novel shows, unredemptively, involved.

Keywords: Romani poetry, poetry and ethics, literature and identity.

Colum McCann has described himself as a writer obsessed with exile (Interview). His most recent novel, Zoli, based on the life of Polish Romani poet Bronislawa Wajs, or 'Papusza' as she was also known, layers several varieties of exile upon each other. ${ }^{1}$ But the novel also does something more than this, delivering aspects of the topology or strange spatiality of the Romani experience in Eastern Europe. In putting into a novel some aspects of the history of the Romani poet who was exiled from her people as the result of her poetry having been published, contrary to her wishes, McCann invites us to contemplate the unexpectedly destructive, as well as the ideologically reconstructive, power of the printed word. There is a sense-of which the novelist is aware ${ }^{2}$-in which non-Roma cannot learn about the Romani experience through reading about it. But we can begin to understand, by means of a novel such as this, some of the historical reasons for this difficulty of access, and why some of those difficulties persist today.

One of the means by which the difficulty of accessing Romani experience is conveyed is the gaps in the life of Zoli Novotna, the character based on Papusza, that are built into the novel. We see her in childhood, young adulthood and old age but the middle years of her life are missing. The missing years are also the years in which Zoli does not herself put pen to paper, only doing so, at the age of seventy three, to write to her daughter in Paris. In this way McCann builds something of Zoli's intentionality and agency into his novel, for she comes to regret ever having allowed her songs to be written down as poems, let alone published, even before she is cast out of her community—branded with the judgement: 'pollution for life' —for 
having done so. The agent of publication is Martin Stránsk , a Slovakian writer based on the figure of Polish writer and activist Jerzy Ficowski, who heard Papusza sing in 1949 and soon after published some of her songs in the magazine Problemy. Zoli is also influenced by a partSlovak Irishman with a zealous attachment to socialist reform, Stephen Swann, with whom she has a secret love relationship. Ficowski, like Swann and Stránsk , saw Papusza as a figurehead for the rehabiliation of her people, but the state-socialist policy of assimilation fell far short of delivering the freedom it promised.

The novel highlights the structural power and damage that can be wrought by the printed word, then, before we consider its content. It is not a book about banned literature in the sense that Joyce's Ulysses and Lawrence's Lady Chatterley's Lover were banned. It is a novel about how a people have built a life in part around the exclusion of printed words, and of much else that gadje or gadzo take for granted. I will take this incorporation of the excluded middle in the novel as my theme, because it also has bearing on the topology of Romani experience, the way in which Roma have had to convert an exclusion from settled society into a form of cultural identity in which they performatively exclude the culture that excludes them, while retaining a sense of an uninterrupted history and tradition (Stewart, pp. 232-42). ${ }^{3}$ As a form of identificatory politics, this doubled exclusion carries obvious risks. But it also requires significant imaginative ability and is, I would argue, its own kind of narrative or world-making work.

As Isabel Fonseca writes in Bury Me Standing, Gypsies or Roma are perhaps unique among peoples, having 'no dream of a homeland' (p. 5). Gypsies' way of living strikes at the heart of the most cherished, but also the most overdetermined, of western values: the belief that a person gathers meaning in the world, and a reward of invisibility, by building a life around a settled home. By contrast, Roma have almost never known the privilege of invisibility. Historical accounts suggest that they were not originally or intrinsically a nomadic people, but travelled-most likely, initially, from India-to escape poverty, war, 
and persecution (Kenrick and Puxon, p. 14, Shashi, cited in Barany, p. 10). One of the 'key policy objectives in medieval Central and Western Europe was to expel, banish, or deport the Roma,' even while they were certainly not the only peoples in this period to practise a travelling way of life. During the Second World War, some 500,000 Gypsies were exterminated by the Nazis (Barany, pp. 10-11; Stewart, p. 5). There does not seem to have been a time when they were not the bearers of some form of social stigma.

Zoli is set in the period of Eastern European Romani history that followed the war, when communist reformers sought to assimilate Roma into the rest of the population, a move that Michael Stewart observes had the same end as fascist endeavours. In both world views and modes of practice, '[t]he Gypsies were to disappear.' Communist reformers saw the Gypsies, who lived in hovels and, even, in places such as Budapest, in caves, as unwholesome remainders of a past to be visibly repudiated, a 'deeply uncivilized legacy' of capitalism (Stewart, pp. 56). The dynamic Zolidramatises is one in which reformers used Gypsies as a symbolic and material linchpin for plans to integrate the entire population: if they could succeed in integrating the Gypsies, who had always been outsiders, then the communist way of life would be shown to be successful indeed.

Yet while Roma were seen as remainders of capitalism-the lumpen proletariat par excellence - the fact that their marginal position had been partly created by the settled cultures with whom they have always interacted went unacknowledged. The reformers' plans for Roma depended on the understanding that Roma were the same as other citizens, or would become like other citizens if they were treated in the same way. As representatives of the socialist utopia Roma became, as Zoli does, theatrical representatives of their own disappearance, frontmen and -women for their ceasing to be. Representing Roma as poster men and women for the dream of a newly equal society, that is, as different from their compatriots, was also a form of double dealinga characteristic long associated with Roma-that was not admitted or 
addressed. When efforts at integrating or 'disappearing' Romani culture into the new society born of revolution failed, Roma accrued not only the doubleness of the reformers' role in their shared history prior to reform but another layer of non-integration born of the hopes of the reformers. And they became more contentiously visible than before (Stewart, p.7).

Within Zoli's own story, there are also instances of doubleness. If Roma are co-created by those who insist on seeing them differently to themselves, against whom Roma build a mobile working identity, Zoli, too, engages with gadzo in inadmissible ways. For a time, while she is fêted by the reformers, the disapproval from within the community that attends any Roma who read and write is in abeyance, but the love affair she has with Stephen Swann would never be tolerated and must be kept secret. Thus, when Stephen publishes her poems against her wishes, she experiences a double betrayal—of her words, and of her trust in him-that is tripled when she is sentenced with 'Pollution for Life in the Category of Infamy for the Betrayal of Roma Affairs to the Outsiders' (p. 115).

There are further layers of betrayal in the story. It has been suggested that for Roma the Romani language substitutes for territory (Williams, p. 389, cited in Stewart, p. 235), and with this in mind we can better understand the community's response to Zoli's poetry, even though she writes in Slovak. Like Zoli, whom Stránsk sees as 'the perfect proletarian poet' in his argument 'against the idea that a smaller language was useless' (p. 62), Eastern European Gypsies were made liminal in new ways in the 1950s and 1960s. When Zoli is made a symbol for the promise of the end of Roma exile-'Citizens of Gypsy Origin, Come Join Us, ' The new tomorrow has arrived,' as the signs read (pp. 49-50) - she unwittingly becomes the symbol of the brutal events that follow: destruction of encampments, enforced relocation in apartment tower blocks, the burning of caravans and the sacrifice of wheels.

Romania was the first state to confiscate Gypsy horses and wagons from 1946, while in 1956, the USSR ordered all nomadic groups to be 
settled swiftly (Destroying, pp. 17-19, cited in Barany, pp. 118, 120). In 1958 the Central Committee of the Czechoslovak Communist Party passed a law which 'deprived "nomads" of the right to travel' and forced them into regular employment. In 1965, Slovak authorities recommended 'to local administrators that no community should include more than 5\% Roma,' while in the 1970s, Roma in the Czech Lands and Slovakia were moved from settlements to communal urban apartments. Schools punished the use of Romani language, even outside of class. And from the 1960s until the 1980s, many Czechoslovakian Gypsy women were sterilised, as were many in eastern Slovakia (Sediv and Marosi, p. 21; Davidová, p. 122, cited in Barany, pp. 117-8; Fonseca, p. 240).

When the wheels of the caravans are burned, in the novel, as a result of the above such measures, it is as though the forest itself is burning, so that the more generative liminality by which Roma express their relation to the land they travel through and camp upon disappears:

The hubs were of elm. The spokes mostly oak. The rims were made from felloes of curved ash ... They were hauled in from riverbanks, deep forests, fields, edges of villages, long, empty, tree-lined roads . . . Sledgehammers were used to remove them. Two-man saws. Levers. Tyre irons. Mallets. Pneumatic drills. Knives ... Policemen stood and watched as the embers made silent passages into the air. Army sergeants leaned in and lit cigarettes. Teachers gathered classes around the flames (p. 103).

Zoli's giving up of Roma songs in the form of published poetry is akin, then, to giving up territory, which does not mean land so much as the means of movement through which her people express belonging to their history and to each other.

'Gypsies,' as Fonseca notes, 'have no myths about the beginning of the world, or about their own origins,' yet 'they have turned the 
enigma of their origins to advantage' (pp. 243, 237). Presentism and performativity are key: while songs provide a sense of history, linguistic skill is a matter of survival, since Roma identity involves responding to gadzo perceptions of Roma in ways that maximise opportunities to earn a living and move freely. Stewart has written persuasively, for example, of the ways Romani horse dealing in Hungary is rendered enjoyable and effective by skillful language, including judicious use of curses and cajolery. 'Through speech,' he observes, the Rom, as they say, 'make money turn around, turn around and come to us,' emphasising

the ease with which this might be done as a dealer 'rotated' goods between customers ... What the Rom had done, in effect, was to treat the market as an arena where glory might be achieved by the performance of heroic feats that turned the tables of hierarchy and power within which they lived. In this sense, the Rom had held onto or reinvented an original and fuller meaning of the idea of 'commerce' as the animated intercourse between persons ... [And s]ince the Rom behaved as if dealing were a form of gambling in which success was determined by 'luck,' they always lived in hope that money would come to them... By putting their money in horses, and moving these around in time and space, traders appeared to make money produce more of itself and so appeared to lead 'the easy life' that the peasants so despised (pp. 161-2).

Hard work goes into movement and into creating the illusion of movement-here, the movement of money and horses-work that in turn disappears. The burning of caravan wheels, then, is not only the destruction of the Roma way of life but also an attack on the ways in which Roma create for themselves the sense of an ever mobile future, given the poverty and disadvantage with which they live. ${ }^{4}$ 
In Zoli, songs are like running water, a key means of the establishing of Roma identity. While for Stránsk and Swann, Zoli is 'a new sort of Czechoslovakian woman, taken out of the margins to illustrate ... steps forward under Socialism,' she does not read for her own people but sings, 'which is what they wanted ... her voice, the secret of it, the one thing that was theirs' (p. 81). Published words, however, are like ice, hiding the logic by which they change meaning as a freeze hides flow, as the words on the signs 'The new tomorrow' and 'Come Join Us' become Law 74, the Great Halt, and the programme of enforced settlement. Ice has bitter memories for Zoli. The primal scene of her life story, and the first scene in the novel, is one in which all the members of her extended family, except herself and her grandfather, are murdered by Hlinka (Slovakian pro-Nazi) guards, who drive them into the middle of a lake in winter:

Fires were lit in a ring around the shore and guns were pointed so they could not escape. The caravans were forced to the middle of the lake as the day grew warmer. The ice cracked, the wheels sank, and the rest followed, harps and wheels and horses. I did not see any of it happen, daughter, but I could hear it in my mind and, although there was great music to come along later ... that will always be a time of looking backwards, listening and waiting for my dead family to catch up (p. 13).

An island in the middle of a lake disappears, and later, so do caravans and encampments, and fires around which there once was singing. The Romani hearth, which centralises freedom of movement, is sucked out of the Romani world. But like running water, songs can move in two directions, forward in the sense that they lead to the transcribing and publishing of Zoli's poetry and her use by the authorities as a figurehead for another disappearance, but also back, as one of few ways by which she and her grandfather are able to remember 
her lost family. They are also the means of bonding with other Roma in the absence of kin (pp. 20,27). As Gigi Thibodeau puts it, '[t]he tradition of singing songs about exile is precisely what has helped hold the Roma together generation after generation: we are alone, but we are alone together' (Thibodeau).

It is Zoli's grandfather, Stanislaus, who teaches her to read, and who finds her a rare husband who will let her to go on reading and writing. Yet as if in compensation for having allowed her to read and to own books-Stanislaus himself has a precious book, a copy of Das Kapital, which gets him into fierce debates among his people-he tries to impress upon her the dangers of words and the significance of the travellers' relationship with movement, music, and running water: ${ }^{5}$

Grandfather took me down to the river. He tipped his hat and brought me across a fallen log, and he held my hand as we balanced near the edge. Listen to me, Zoli, he said. The river here, it doesn't belong to anyone, but some of them say they own it, even some of us say we own it, but we don't. Look there, see the way the water is still moving underneath? It'll keep on moving. Only inches below, girl, the owning is gone, even ours, and you have to remember that, otherwise they will make a fool of you with their words. The next day he led me to the schoolhouse (p. 30).

Soon after, Zoli's friend Conka's mother has her fingernails pulled out by Hlinkas in the back of a bookshop, so that she can no longer pluck the harp strings that accompany the kampanija's songs. The bookshop is burned down in revenge.

After the Judgement which outlaws Zoli from her community, and which takes place after she has begged Swann not to allow her poems to be published, she takes upon herself the role of remaining true to her people's history, now that it is lost, as well as living out her own. Here the dynamics of exclusion and exile become more complex. At the point 
at which events become most brutal for Slovakian Roma, Zoli's public image shifts:

A new tomorrow was on the way... and it would include the Roma people. Zoli was the subject of a whole new series of editorials that professed she had been painting the old world so it could finally, at last, change. They saw her as heroic, the vanguard of a new wave of Romani thinkers. One of her poems had been reprinted in a Prague-based university journal. Tapes of her singing were played again on the radio. The further away she was the bigger she had become... The idea of [Gypsies] living out in the forest had become bizarre and old-fashioned, almost bourgeois (p. 88).

Because the material trace of Zoli's voice-on the airwaves, on printed paper-has been used to inflict such lasting damage, after the Judgement she ceases to be Romani, becoming instead that which simply remains: 'If she touched any Romani thing it would be destroyed, no matter what value ... She would not have a funeral. She could not come back, even as a spirit... She ... was beyond dead, not Gypsy, not gadzi, nothing at all' (p. 116).

In her new, bare existence, however, Zoli testifies to, and performs, that which her former people can no longer do freely: walk the roads. She marks a space of disappearance as she once marked a space of hope. Her torn and bleeding feet, from which flaps of skin fall when she removes her shoes, become the equivalent of the destructive work that followed from putting song into words onto paper. She reinscribes the history of her family's murder on the fire-ringed ice as she washes her feet in a stream's 'burning cold' (p. 153). Her feet become, in a sense, poetic remnants, the outcome of that earlier work of mistaken innocence. For earlier, the transforming of her songs into poetry was expressed by Swann, in his reading of Zoli, as a process of movement through landscape: 
Zoli improvised as she went along-[Stránsk would] ask her to repeat a certain verse so he could transcribe it, and the verse would shift and change. It seemed to me that her words contained simple, old-fashioned sounds that others had forgotten or didn't know how to use any more: trees, pools, forest, ash, oak, fire (p. 63).

This process of movement becoming song, which in turn becomes printed matter, is the one that Zoli, after having found the originals of her poems in Swann's lodgings and setting fire to them, now undertakes to reverse. There is an argument to be made here, I think, about the ethical function of art and poetry. Eric Santner and Joan Copjec each raise questions, in different ways, to Elaine Scarry's influential discussion of beauty as symbolising the moral form of human justice, in a debate that has bearing on McCann's novel (Scarry). Santner charges Scarry with omission of 'the remnant immanent to the beautiful.' As a sign of the 'interrupted or self-interrupting whole,' he claims that the beautiful does not figure 'an equipoise and symmetry missing from the rest of life,' as Scarry argues, but instead 'moves us because its own formal composition and procedures produce more reality than it can contain.' What poets establish, he suggests, 'is not some sort of vision or consciousness of the All,' but rather 'they introduce into the relational totality of existence-into the social body divided into parts-the perspective of "non-all"' (pp. 140, 142). This 'non-all' is not simply one component of a generality named 'society' but a singular, non-replicable dimension where the word produces an excess that was not directly required of it. And as Copjec notes, in terms of considerable relevance to the history of Roma and the violence of their intended assimilation:

[A]lthough Scarry speaks of the beauty of balance and symmetry, one is as likely to be horrified by them: a harmonious whole with all its parts snugly in place can just 
as easily describe the architectural plan of a police state, rendered as all such plans are from a transcendent point of view (Imagine, p. 172).

In a discussion of Sophocles's Antigone, Copjec elaborates on Lacan's claim, made in his ethics seminar, that 'the only thing of which one can be guilty is of having given ground relative to one's desire' ( $p$. 319). Lacan makes clear that this giving ground often occurs by means of the best of motives, such as Zoli's desire to collaborate with Stránsk in giving form to the history and life of her people. Copjec argues that Antigone's resolve to honour her brother Polynices by identifying herself with, and remaining with, his body once it has been denied a proper burial by Creon, the king who stands in Polynices's place, is, however, an instance of such refusal to give ground. It is not an unconscious binding to the enjoyment of one's suffering-not, that is, a form of righteous indignation which can be used to shore up one's claim to ideal behaviour-but rather an act of encircling a meaningfully opaque place in the socius. Like, that is, Zoli's relentless, circular travelling of roads.

In identifying with her dead, dishonoured brother, Antigone testifies not only to the value of the patch of earth on which he lies but also to a significant absence of meaning: something that should have occurred has not occurred for reasons that have not been given:

Antigone's perseverance does not consist in the repetition of a 'pattern of behavior,' but of the performance, in the face of enormous obstacles, of a creative act, and it results not in the preservation of the ... core of her being ... but of its complete overturning. Antigone's perseverance is not indicated by her remaining rigidly the same, but by her metamorphosis at the moment of her encounter with the event of her brother's death and Creon's refusal to allow his burial. She remains faithful ... not to herself, but to the terrible misfortune-or 
ate-that befalls her... The image she presents is not one of pathos; it destroys the point of identification rather than encouraging us to identify with her ('Tomb,' pp. 258-9).

And in a similar way to that in which Antigone challenges, in her person, the transmutation of earth into the grounds on which a leader might rightfully claim to rule-in effect, her person is and becomes the substance of the missing logic, the missing right, of Creon's kingship, standing for its non-elaboration-so Zoli finds and passes through the camps from which her people have been burned and banished. Sheltering in a hut in the forest, she wonders:

What might it be like to stay like this for ever ... moving back and forth between forest and hut, over the empty field, through the colourless rain, eating pine seeds, watching the flame crackle? To lie on the floor and slip down into the boards, to wake again in silence, saying nothing, recalling nothing, with not a soul in sight, to have her name pass silently into the walls of the hut? (p. 117)

Like Antigone, she places herself in the site of the missing rationale of the way of life that rules and gathers power, for 'moving back and forth between forest and hut,' and 'slip[ping] down into ... boards' is a form of gadzi life, and the life led by peasants in rural Slovakia, after all. Yet in the efforts to assimilate her people no claim as to the essential rightness of settled living was made. Its rightness was assumed, and the extent to which Roma would benefit from it was also.

As Zoli continues in her new exilic journey she too, like Antigone in Copjec's reading, 'continue[s] to pursue fresh sublimations' ('Tomb, p. 262). Sublimation is the act by which the human will to repeat behaviour in search of lost satisfactions circles around the remembered object that once gave such satisfaction-in this case, the act of belonging to, by travelling through, the land. Fresh sublimation is not automatically provided by the act of travelling, however, for sublimation entails 'the 
invention of new ways of keeping faith with the lost or dead Other'the lost or dead world view and form of world-belonging-'even to the point of abandoning every last vestige of one's being, that is, of the very object upon which one's fantasy' or sense of self depends (p. 262).

This process is effected when Zoli, having escaped across the border from Slovakia to Austria with the help of a prisoner in a forest workcamp, lives in a camp for Displaced Persons and meets another Roma, a woman named Mozol, with whose family she lives. When Mozol, whose one desire is to travel to and resettle in Toronto, but who cannot pay the required part of her passage, is in her despair over her lost hopes, Zoli forgets her old life and makes a decision to embody, in Mozol's cause, the dead remains of the worst gadzi beliefs about Gypsies:

We fall out of rhythms with our earliest ways ... I even forgot I was polluted ... and in some ways I had begun to think of myself as Mozol's sister. The decision had no fear. Sometimes you make up your mind about something without knowing why. I knew the town well. I did not like what I was about to do, daughter, but I had forced myself not to think about it. I cut the nerve that twitched in me and went to the dump at the edge of town (p. 203).

Zoli finds a cupboard door on which she carves 'maple leaves and a griffin,' makes 'two grand rubber earrings' from 'parts of a discarded carburettor,' adds a Spanish scarf, picks up pebbles, and later that day sets herself up as a Gypsy fortune teller in an alleyway in town (p. 203).

She is successful, especially with young men, and is able to give Mozol enough money to pay for the required part of her journey, but this act is a complex one of looping back through the estranging dimensions of her history. If Antigone's metamorphosis is 'a surrendering of the grounding substance that supports fantasy and a grounding of the world in the act' ('Tomb,' p. 262). Zoli too stakes a 
claim to contested territory, or territory with a missing logic, as the gadzi image of the Gypsy is a fantasy without substance, and it is this very missing substance that she now becomes:

I kept expecting troopers to round the corner, or some dead family spirit to lean in from a doorway to see what had happened to me, how I had betrayed all that I had ever known. I had no name for what I had become, it did not exist in either pain or pleasure (p. 205).

No name, no word, no poetry. No repetition of an earlier crime, but the elaboration of a new one, born of gadzi repetitions, stock images of Gypsy ways. One falsity - the publishing of poems and the damaging misuse of her image by the gadzos - is met with another, as outcast status goes to work to redeem Mozol's exile. Mozol's defining characteristic is an inability to stop talking, in a careless, harmless way that is the reverse of the collaborative word-work in which Zoli once engaged. The ashes of Zoli's burned poems become the ashes and dust of her new detour around the missing heart of her identity, gathered from the dump at the edge of town.

Zoli does not tell Mozol of her polluted status, but instead performs this creative act that is a kind of traffic in nothingness, a wager with what might be left of her soul. Responding to Scarry, Copjec points out that Scarry's response to Kant's 'enigmatic formulation: beauty symbolizes our morality,' has got people 'stumped' by encouraging us to look for a particular 'representation of the will or of what will has the power to bring about.' But '[w]hat if,' she asks,

there were a type of symbolization that did not function to represent something, but that made nothing appear? What if the beautiful were not a representation but, in Lacan's vocabulary, a semblant, an apparent nothing or that which made nothing appear? This raises a further question: why 
would nothing incite an autonomous or ethical will to action? (Imagine, p. 172)

An ethical will to action, in Kantian and Lacanian terms, would need not to elaborate itself on the basis of a general law, which will always take us back to ground given up for allegedly good reasons. 'Resettlement. They want to give us schools and houses and clinics . .. They're saying we used to be backward. Now we're new ... They call it Law 74,' as Zoli says to Swann (p. 93). The logic of such efforts regards pleasure and happiness as little more than a material good that can be quantitatively divided and shared out, to which, it is believed, everyone should have equal access. 'The problem [of pleasure] should not be posed as one of distribution,' however, argues Copjec, 'but of deprivation instead' (Imagine, pp. 173-4). People ought to be allowed the right to go without things that others wish them to have. When Swann meets Zoli, he notes that

[a]s a singer she could have lived differently, with no scrubbing, no cooking, no time spent looking after the children, but she didn't isolate herself, she couldn't, she was in love with that bare life, it was what she knew, it fuelled her. She washed clothes in the river, beat the rugs and carpets clean. Afterwards she put playing cards in the spokes of a bicycle wheel and rode around in the mud, calling out to the children ... [She] was well known among her people, settled and nomadic alike. she touched some old chord of tenderness in them. They would walk twenty kilometres to hear her sing (p. 73).

It is in choosing what to do without, as much as what to have, that Zoli's life has meaning before she becomes 'something exotic to fall in love with' (p. 107), and before her world gives way.

An art which makes nothing appear, then, as I think McCann's novel, or Zoli's act on behalf of her not-quite sister within McCann's 
novel, does, shows the singular human being as that for which no place of ultimate belonging in the world could be prepared, and on whom it is thus incumbent to create the possibility of such a belonging. This is what Zoli attempts to do for Mozol, without any thought of her own redemption. And when she later finds the man who assists her across a final border and becomes her husband and father to the daughter to whom she writes, the two exchange an absence of words that is the most meaningful version of nothing they could express. 'I asked Enrico why he had not asked me anything about being a Gypsy'-this being inseparable, for most gadzos, from the intriguing image about which gadzos desire to know, in order to confirm them in their own taken-forgranted invisibility and dissatisfaction-'and he asked me why I had never asked him anything about not being one' (p. 223). Here, the fantasy of gadzi belonging is suspended before the more important question of what it is possible for Zoli and Enrico to share with each other. And if what they share is a lostness, an exile-for Enrico, an exile from privilege, for Zoli, an exile from her people-symbolised by their house at the edge of a mountain pass, then this sharing may open onto a future together, as it does.

When Zoli is walking the roads for the first term of her exile, she has a word for a place that keeps her moving, a word for the 'non-All' of Santner's poetic remnant that interrupts the accounted-for world. The word is 'Paris. An absurdity. How many borders is that? How many watchtowers?' Yet, while walking,

[s] he clings to its ridiculousness, its simple repetition. She .. . finds that, as she goes along, it is a sound that helps her think of nothing at all, rhythmically bumping against the air, carrying her forward, a sort of contraband, a repetition so formless, so impossible, so bizarre that it matches her footsteps... (p. 155).

Not so impossible, though. Zoli and Enrico's daughter, Francesca, goes away to live in Paris, and Zoli visits her, at the end of the novel, to attend 
the conference Francesca has organised on 'Romani Memory and Imagination.' Zoli declines the opportunity to speak at the conference. But the novel ends as she and Francesca leave the bedroom where Zoli is sleeping for the living room of Francesca's flat, where her boyfriend has brought a group of Scottish musicians from the event. Zoli asks, 'What happened to the music?' and the story ends as the windows and walls of the room seem to open, and as she lifts her head and begins to sing (pp. 274-5).

She is about to bring the formerly excluded heart of her people's history, a history of lostness, in which the right to celebrate and honour deprivation is one of the most important they can claim, into the hearth space of her daughter's home. This space of lostness, this memory of lostness, of exclusion, was once the heart of her own community, and then only a word-'Paris' - enabling movement, an aid to thinking 'nothing ... formless ... impossible ... bizarre.' And yet, is the repetition of the word 'Paris,' in the exiled days, not also 'a type of symbolization' that 'makes nothing appear' meaningfully? It is a poetic wager upon a future that leads to Mozol, to Enrico, and to Francesca in Paris, where Zoli also meets Stephen again. And as the word merges with Zoli's exiled footsteps which testify to nothing, to the spaces where her people once were and are allowed to be no longer: 'Zoli learns exactly when the first of the word will hit with her heel against the ground, and the last of the word will hit with her toe, so that she is going, in perfect conjunction, sound and step, onwards' (p. 155). This 'onwardness' is also what she finds again in Paris, with Francesca and the musicians, and in her own re-encounter with her calling in song: 'How glorious,' she thinks, 'how joyful, that it is all still, even on this night, so unfinished ..."Go on,"' she says to the musicians: "Play,"' and they do play, and in response to the music '[s] he begins. She begins' (pp. 274-5). 


\section{Notes}

1. As Isabel Fonseca notes, Papusza's people (like Zoli's) were harpists, she was beaten for reading, and, after her marriage, began to compose long ballads, 'part song, part poem, spontaneously "enacted"' (pp. 4-7).

2. In interview (with Michael Hayes), McCann states: 'I know that I didn't get it all right. Who can? Who might want to? Zoli is a failure. All books are.'

3. First described by the mathematician Listing (1808-82) as the '[s]tudy of the qualitative laws of relations of place' from which 'measure and extension are excluded,' psychoanalyst Jacques Lacan used topology to indicate the fundamental foreignness or 'radically ... exterior' nature of that which human beings consider to be their most intimate attributes (see Pont, p. 110, cited in Charraud, pp. 204, 208). In this understanding, the relative invisibility of those who belong to settled cultures is grounded on an act of exclusion: the earth on which houses are built is sanctified by forgetting that it is of the same substance as the outside world. A topological reality-where inside and outside are formed of one continuous substance-is typically rendered through a more simplistic imaginary schema whereby the inside and outside of houses are seen to be spaces of a fundamentally different nature. If we live in houses within a primarily settled culture, we are seen to belong to society, while if we live outside of them, we are not.

4. As Fonseca reports, for example (pp. 232-3), the British Parliament repealed the 1968 Caravan Sites Act, 'which required local authorities to provide land,' in 1994, 'arguing that Gypsies should pay for their own ground. At the same time, the government tightened planning policy, making it virtually impossible for them to do so (and once a piece of land is acquired, it is then necessary to make separate applications for permission to live on it, to build a shed, to build a house, to build a stable, etc.; ninety-five percent of the applications fail).'

5. A reverence for running water has basis in Romani customs and daily practice. Water for washing clothes and washing dishes is kept rigorously separated, because of the 'unspoken . . . but categorical distinction' between the upper and lower body,' so that the face-and also dishes-must never be washed in water that might have touched the lower body. This upper / lower body distinction is an important way in which Roma distinguish themselves from gadzos (see Stewart, p. 208). 


\section{References}

Barany, Zoltan, The East European Gypsies: Regime Change, Marginality, and Ethnopolitics. Cambridge: Cambridge University Press, 2002.

Charraud, Natalie. 'Topology: The Möbius strip between Torus and Cross-Cap,' trans. Dominique Hecq and Oliver Feltham. In A Compendium of Lacanian Terms, ed. Huguette Glowinski, Zita Marks, and Sara Murphy. London: Free Association, 2001, pp. 204-10.

Copjec, Joan. 'The Tomb of Perseverance: On Antigone.' In Giving Ground: The Politics of Propinquity, ed. Joan Copjec and Michael Sorkin (London: Verso, 1999, pp. 23366.

Imagine There's No Woman: Ethics and Sublimation. Cambridge, MA: MIT Press, 2002.

Davidová, Eva. Romano Drom: Cesty Romu, 1945-1990. Olumuc: Vydatelstvi Univerzity Palackého, 1995.

Destroying Ethnic Identity: The Gypsies of Romania. New York: Helsinki Watch, 1991.

Fonseca, Isabel. Bury Me Standing: The Gypsies and their Journey. New York: Alfred A. Knopf, 1996.

Kenrick, Donald, and Grattan Puxon. The Destiny of Europe's Gypsies. New York: Basic Books, 1972.

Lacan, Jacques. The Seminar of Jacques Lacan, Book VII: The Ethics of Psychoanalysis, 1959-1960 [1986], trans. Dennis Porter, ed. Jacques-Alain Miller. New York: W. W. Norton, 1992.

McCann, Colum. Interview with Michael Hayes, <http:/ / www.colummccann.com/ interviews/hayes.htm>.

Zoli. London: Weidenfeld and Nicholson, 2006.

Pont, J. C. La Topologie algabrique des origines Poincar. Paris: Presses Universitaires de France, 1974. 
Santner, Eric L. On the Psychotheology of Everyday Life: Reflections on Freud and Rosenzweig. Chicago: University of Chicago Press, 2001.

Scarry, Elaine. On Beauty and Being Just. Princeton: Princeton University Press, 1999.

Sediv , Vladimír, and Viktor Marosi. Position of National Minorities and Ethnic Groups in the Slovak Republic. Bratislava: Minority Rights Group, 1996.

Shashi, S. S. Roma: The Gypsy World. Delhi: Sundeep Prakashan, 1990.

Stewart, Michael. The Time of the Gypsies. Boulder, CO: Westview Press, 1997.

Thibodeau, Gigi. 'Growing a New Skin: The Life and Poetry of Papusza,' 2003, <http:/ /kmareka.com/free-literature-online/growinganewskin.htm>. 